\title{
THE DOSE-RESPONSE PHENOMENON ASSOCIATED WITH STRENGTH TRAINING IS INDEPENDENT OF THE VOLUME OF SETS AND REPETITIONS PER SESSION
}

Original Article

ARTIGO ORIGINAL Artículo Original

\author{
O FENOAMENO DE DOSE-RESPOSTA ASSOCIADO AO TREINAMENTO DE FORÇA ÉINDEPENDENTEDO \\ VOLUMEDE SÉRIES EREPETIÇÕES PORSESSÃO
EL FENÓMENO DEDOSIS-RESPUESTA ASOCIADO AL ENTRENAMIENTO DE FUERZA ES INDEPENDIENTE
DEL VOLUMEN DE SERIES Y REPETICIONES PORSESIÓN

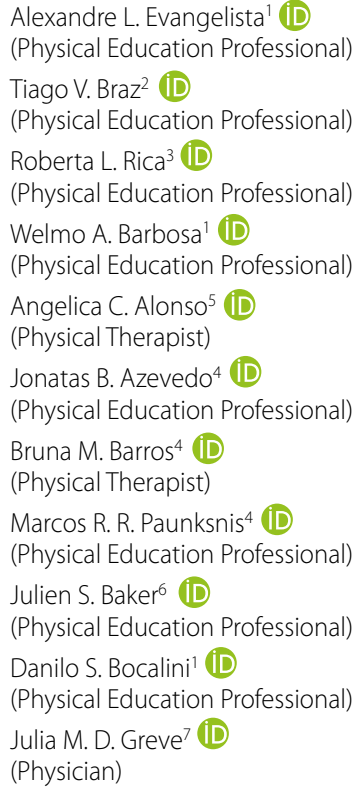

1. Federal University of Espírito Santo, Physical Education and Sports Center, Experimental Physiology and Biochemistry Laboratory, Vitória, ES, Brazil. 2. Universidade Metodista de Piracicaba, Piracicaba, SP, Brazil. 3. Universidade Estácio de Sá, Department of Physical Education, Vitória, ES, Brazil.

4. Universidade Nove de Julho, São Paulo, SP. Brazil.

5. Universidade São Judas,

Department of Aging Sciences, São Paulo, SP, Brazil.

6. Hong Kong Baptist University, Health and Exercise Science Research, Kowloon Tong, Hong Kong, China.

7. Faculdade de Medicina da Universidade de São Paulo, Instituto de Ortopedia e Traumatologia, Laboratory for the Study of the Movement, São Paulo, SP, Brazil.

\section{Correspondence:}

Alexandre Lopes Evangelista. Rua Flávio de Melo, 156, apto 12, São Paulo, SP, Brasil 04117-130. contato@alexandrelevangelista. com.br

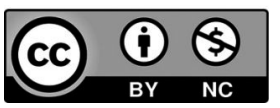

\begin{abstract}
Introduction: There are few studies on the effectiveness of training models with high volume sets per session in particular muscle groups. Objective: The aim of the study was to investigate the effects of different resistance training (RT) repetitions with equalized volumes on muscle adaptations. Methods: This study used an experimental design in which forty-seven volunteers underwent 8 weeks of RT after having been distributed randomly into three groups: ten sets of three maximum repetitions (10x3), three sets of ten maximum repetitions ( $3 \times 10)$ and five sets of six maximum repetitions (5x6) for each muscular group per training session. Maximum strength (1RM test) and muscle thickness (MT) were evaluated as outcomes. Results: A significant main effect $(p=0.001)$ of time on maximum strength was observed for the three groups, but no significance was observed $(p>0.05)$ in time $x$ group interactions. A significant main effect $(p=0.001)$ of time was observed on MT for biceps, triceps and vastus lateralis, without significant differences for time x group interactions. Significant correlations were found between maximum strength and muscle thickness after general statistical analyses for all protocols. Conclusion: Improvements in maximum strength and muscle thickness are similar when repetition volumes are equalized through the number of series and repetitions. Level of evidence l; Therapeutic studies, investigation of treatment results.
\end{abstract}

Keywords: Resistance training; Muscular adaptations; Volume of training.

\section{RESUMO}

Introdução: Existem poucos estudos sobre a eficácia de modelos de treinamento com conjuntos de alto volume por sessão em grupos musculares específicos. Objetivos: O objetivo do estudo foi investigar os efeitos de diferentes repetições do treinamento de resistência (TR) com volumes equalizados nas adaptações musculares. Métodos: Este estudo tem desenho experimental com 47 voluntários que realizaram oito semanas de TR depois de serem distribuídos randomicamente em três grupos: dez séries de três repetições máximas (10x3), três séries de dez repetições máximas (3x10) e cinco séries de seis repetições máximas (5x6) para cada grupo muscular por sessão de treinamento. A força máxima (teste de 1RM) e a espessura muscular (EM) foram avaliadas como desfecho. Resultados: Verificou-se efeito significativo $(p=0,001)$ sobre 0 tempo na força máxima nos três grupos, contudo, nenhuma significância ( $p>0,05)$ foi observada nas interações entre tempo e grupo. Constatou-se efeito significativo $(p=0,001)$ do tempo sobre a EM para bíceps, tríceps e vasto lateral, sem diferenças significativas nas interações entre tempo e grupo. Correlações significativas foram encontradas entre força máxima e espessura muscular depois das análises estatísticas gerais para todos os protocolos. Conclusões: A melhora da força máxima e da espessura muscular ésemelhante quando o volume de repetições é equalizado considerando o número de séries e repetições. Nível de evidência l; Estudos terapêuticos, investigação dos resultados do tratamento.

Descritores: Treinamento de resistência; Adaptação muscular; Volume de treinamento.

\section{RESUMEN}

Introducción: Existen pocos estudios sobre la eficacia de modelos entrenamiento con conjuntos de alto volumen por sesión en grupos musculares específicos. Objetivos: El objetivo del estudio fue investigar los efectos de diferentes repeticiones del entrenamiento de resistencia (ER) con volúmenes ecualizados en las adaptaciones musculares. Métodos: Este estudio tiene diseño experimental con 47 voluntarios que realizaron ocho semanas de ER después de ser distribuidos aleatoriamente en tres grupos: diez series de tres repeticiones máximas (10x3), tres series de diez repeticiones máximas (3x10) y cinco series de seis repeticiones máximas (5x6) para cada grupo muscular por sesión de entrenamiento. La fuerza máxima (test de 1RM) y el espesor muscular (EM) fueron evaluados como conclusión. Resultados: Se verificó efecto significativo ( $p=0,001)$ sobre el tiempo en la fuerza máxima en los tres grupos, sin embargo, ninguna significancia $(p>0,05)$ fue observada en las interacciones entre tiempo y grupo. Se constató efecto significativo $(p=$ 0,001 ) del tiempo sobre el EM para bíceps, tríceps y vasto lateral, sin diferencias significativas en las interacciones entre 
tiempo y grupo. Fueron encontradas correlaciones significativas entre fuerza máxima y espesor muscular después de los análisis estadísticos generales para todos los protocolos. Conclusiones: La mejora de la fuerza máxima y del espesor muscular es semejante cuando el volumen de repeticiones es ecualizado considerando el número de series y repeticiones. Nivel de evidencia l; Estudios terapéuticos, investigación de los resultados del tratamiento.

Descriptores: Entrenamiento de resistencia; Adaptaciones musculares; Volumen de entrenamiento.

\section{INTRODUCTION}

Supported by bodybuilding models, the prescription of resistance training focusing on muscular hypertrophy had been well investigated ${ }^{1-6}$ and usually adopts high volumes of sets per muscle group per training session 7 . Snyder and Wayne ${ }^{8}$ cite that elite bodybuilding athletes typically adopt volumes between 9 and 24 sets, while other ${ }^{9}$ indicate volumes of up to 49 sets per muscle group in a single training session.

This proposal considers that, for muscle hypertrophy development, we need to consider the stimulus volume, the magnitude of mechanical tension, metabolic stress, the levels of substrate depletion, metabolite accumulation and tissue damage during training. These factors, consequently, generate better anabolic responses in the presence of adequate recovery ${ }^{10,11}$. In fact, the literature has shown that higher training volumes have provided high myofibrillar protein synthesis responses ${ }^{12}$ and several chronic studies support higher training volume by maximizing muscle hypertrophy. This has been suggested in a recent meta-analysis ${ }^{13,14}$. However, there are only a few previous studies comparing strength gains and muscle hypertrophy between multiple session protocols with different amounts of activity performed during training sessions $s^{8,15}$.

There is a lack of studies to support the effectiveness of models with high volume sets on particular muscle groups per training session, such as those commonly adopted in gyms by trained individuals ( $\geq 10$ sets per muscle group). On the other hand, some studies suggest that smaller training volumes per muscle group may be sufficient to promote relevant increases in muscle strength and hypertrophy in untrained ${ }^{3,16}$ and trained individuals ${ }^{15}$, especially in the upper limbs ${ }^{7}$.

Recently, Kubo et al. ${ }^{17}$ showed that the increase in muscle size was similar after 10 weeks of resistance training using three training protocols with training volume equated, nevertheless, muscle strength was lower with the 12RM protocol compared to other protocols. Additionally, on practical applications is very usually coaches and athletes address the exercise protocol by repetition zone especially to untrained subjects. However, considering that there is little robust evidence evaluating the high number of sets per training session as well as the recommendation of the number of sets to maximize neuromuscular adaptations in untrained individuals still unclear. In this way, the aim of the present study was to investigate the effects of different weekly sets performed on muscle groups and investigate the morphological functional responses in untrained individuals.

\section{MATERIAL AND METHODS}

\section{Sample}

This study utilized a randomized experimental design was approval from the Ethics Research Committee of Nove de Julho University ( $n$ : 2.549.504/2018) and signed an informed consent form, sixty-six healthy, physically active and untrained subjects volunteered to participate in the study. All subjects were recommended to maintain the same nutritional intake over the study period. The following parameters were used as exclusion criteria: positive clinical diagnosis of diabetes mellitus, smoking, musculoskeletal complications and/or cardiovascular issues confirmed by medical evaluation, experience in resistance training. The volunteers were randomly distributed in three groups: ten sets of three maximal repetitions $(10 \times 3)$, three sets of ten maximal repetitions $(3 \times 10)$ and five sets of six maximal repetitions $(5 \times 6)$ for each muscular group per training session. The randomization process occurred in blocks of six subject. Each block resulted in the allocation of two subjects to each group, ensuring a recruitment balance throughout the study.

\section{Study design}

During the study period, 13 individuals dropped out due to personal reasons, leaving 18 subjects in $3 \times 10,14$ subjects in $10 \times 3$ and 15 subjects in $5 \times 6$ groups, respectively and all were included in the statistical analysis as outlined in Table 1. None of the subjects had any experience with resistance training for at least six months prior to the experimental period but were physically active in other types of activities (recreational sports and/or endurance training) in concordance with previously study ${ }^{18}$.

All the training groups trained twice a week for 8 weeks. Subjects performed maximum repetitions with 90 -seconds rest between sets. Maximum strength and muscle thickness were assessed before and after 8 weeks of training using one-repetition maximum (1RM) and ultrasonography assessments of the biceps, triceps brachii, and vastus lateralis muscles. The total repetitions was utilized as parameter to training equalization.

All subjects completed two familiarization sessions interspersed by a minimum of 72 hours before the commencement of experimental protocol, both of which occurred one week after the maximum dynamic strength and muscle thickness assessments. During these sessions, subjects were familiarized with the exercises and consolidated proper lifting techniques.

Subjects underwent a hypertrophy-oriented ST regimen twice a week (at least 48 hours between training sessions) for 8 weeks. Ten ( $3 \times 10)$, three $(10 \times 3)$ and six $(5 \times 6)$ sets were performed for each of the exercises: biceps curl, squat and triceps extension (high pulley). The exercises were performed with free repetition and a 90-second rest interval was observed between sets. Exercises and repetition schemes remained the same for all 8 weeks in all groups. If a subject was able to perform one or two more repetitions, the load was increased by 2-10\% for upper body and $2-15 \%$ for lower body exercises ${ }^{19}$. Each training session lasted approximately between 20 and 60 minutes.

\section{Measurements}

\section{Maximum strength test}

Maximum dynamic strength was assessed using 1RM testing for the biceps curl, back squat and high pulley triceps extension exercises (Nakagym ${ }^{\circledR}$, São Paulo, Brazil). The testing protocol followed previous recommendations by Haff \& Triplett ${ }^{2}$. Subjects reported to the laboratory,

Table 1. Subject characteristics.

\begin{tabular}{c|c|c|c}
\hline Parameters & $\mathbf{3} \times \mathbf{1 0}$ & $\mathbf{1 0 \times 3}$ & $\mathbf{5} \times \mathbf{6}$ \\
\hline Age (years) & $23.5 \pm 1.2$ & $23.3 \pm 0.9$ & $23.6 \pm 1.0$ \\
\hline Body mass $(\mathrm{KG})$ & $72 \pm 9$ & $72 \pm 14$ & $72 \pm 13$ \\
\hline Heigth $(\mathrm{cm})$ & $171 \pm 0.08$ & $169 \pm 0.05$ & $170 \pm 0.08$ \\
\hline
\end{tabular}


at the same time of day having refrained from any exercise other than activities of daily living for at least 72 hours prior to the testing sessions both before and after the intervention

Subjects warmed up for 5 minutes on a treadmill (Movement technology ${ }^{\circledR}$, São Paulo, Brazil) at $60 \%$ of maximum heart rate followed by two exercise-specific warm-up sets. During the first set, subjects performed five repetitions at $\sim 50 \%$ of the estimated $1 \mathrm{RM}$ followed by one set of three repetitions at a load corresponding to $\sim 60-80 \%$ of the estimated $1 \mathrm{RM}$ with 3-minute rest interval between sets. Following the warm-up sets, subjects had five attempts to find their 1RM load with 3-minute intervals between trials.

\section{Muscle thickness}

Ultrasonography was used to determine the muscle thickness (MT) of the biceps brachii and brachialis (BB), triceps brachii (TB) and vastus lateralis $(\mathrm{VL})$ using an ultrasound-imaging unit (Bodymetrix, BodyMetrix, BX2000, IntelaMetrix, Inc., Livermore, CA) with a wave frequency of 2.5 $\mathrm{MHz}$ according to a previous publication ${ }^{20,21}$. The ultrasound probe was applied perpendicular to the skin for measurement. A water-soluble gel was used on the transducer to aid acoustic coupling and remove the need for excess contact pressure on the skin. MT was defined as the distance between the interface of the muscle tissue and sub-cutaneous fat to the corresponding bone. Imaging was performed on the right side of the subject's body. The subjects were instructed to fast for at least 3 hours prior to testing and assessments were performed at the same time of day for pre and post-testing.

\section{Statistical analysis}

The normality and homogeneity of the variances were verified using the Shapiro-Wilk and Levene tests, respectively. Prior to analysis, all data were log-transformed for analysis to reduce bias arising from nonuniformity error (heteroscedasticity). The mean, standard deviation (SD) and $95 \%$ confidence intervals $(\mathrm{Cl})$ were used after data normality was assumed. A repeated measure analysis of variance (ANOVA) was used to compare $1 R M_{\text {biceps curl, }} 1 R_{\text {squat, }} 1 R M_{\text {elbow extension, }}$ muscle thickness of the $B B, T B, V L$ and accumulated training load (ATLL) time effect (before vs after training) $x$ three groups ( $3 \times 10$ vs. $10 \times 3$ vs $6 \times 5$ ). Post hoc comparisons were performed using the Bonferroni correction. Assumptions of sphericity were evaluated using Mauchly's test. Where sphericity was violated $(p<0.05)$, the Greenhouse-Geisser correction factor was applied. In addition, effect sizes were evaluated using a partial eta squared $\left(\eta^{2}{ }_{p}\right)$, with $<0.06,0.06$ 0.14 and, $>0.14$ indicating a small, medium, and large effect, respectively. Effect sizes in absolute differences (before vs after training) in raw values of the variables using the standardized difference based on Cohen's $d$ units by means ${ }^{13}$. The $d$ results were qualitatively interpreted using the following thresholds: < 0.2, trivial; 0.2-0.6, small; 0.6-1.2, moderate; 1.2-2.0, large; $2.0-4.0$, very large and; $>4.0$, extremely large. If the $90 \%$ confidence limits overlapped, small positive and negative values for the magnitude were deemed unclear; otherwise that magnitude was deemed to be the observed magnitude ${ }^{22}$. Trivial area $d<0,2$ (gray bar) was used in Forrest Plot Graph. All analyses were conducted in SPSS-22.0 software (IBM Corp., Armonk, NY, USA). The adopted significance was $P \leq 0.05$.

\section{RESULTS}

As shown in Table 2 a significant main effect of time in the variables $1 \mathrm{RM}_{\text {biceps curl }}\left(F_{1,13}=326.134, p=0.001, \eta_{p}^{2}=0.962\right), 1 \mathrm{RM}_{\text {squat }}\left(F_{1,13}=143.461\right.$, $\left.p=0.001, \eta_{p}^{2}=0.917\right)$ and $1 \mathrm{RM}_{\text {elbowextension }}\left(F_{1,13}=206.891, p=0.001, \eta_{p}^{2}=0.941\right)$ was observed. There were no significant differences in time $x$ group interaction for $1 \mathrm{RM}_{\text {biceps curl, }} 1 \mathrm{RM}_{\text {squat, }} 1 \mathrm{RM}_{\text {elbow extension }}$ (all $p>0.05$ ).

A significant main effect of time was observed for $B B\left(F_{1,13}=175.536\right.$, $\left.p=0.001, \eta^{2}=0.931\right), \mathrm{TB}\left(F_{1,13}=210.457, p=0.001, \eta_{p}^{2}=0.942\right)$ and $\mathrm{VL}$
$\left(F_{1,13}=163.963, p=0.001, \eta_{p}^{2}=0.927\right)$ (Table 3). There no was significant difference in time $x$ group interaction for BB, TB and VL (all $p>0.05$ ).

At Figure 1 outlines the ES analyses. Absolute differences after 8 weeks between $10 \times 3$ vs $3 \times 10$ groups was small for $1 \mathrm{RM}_{\text {elbow extension }}(\mathrm{d}=0.26, \mathrm{IC} 90 \%=$ -0.17 to 0.69$), 1 R M_{\text {biceps curl }}(d=-0.22, I C 90 \%=-0.55$ to 0.11$)$, TB ( $d=-0.24$, IC90\% $=-0.61$ to 0.13$)$ and trivial $1 R M_{\text {squat }}(d=-0.12, I C 90 \%=-0.41$ to 0.17$), V L$ $(d=-0.11, I C 90 \%=-0.46$ to 0.24$), B B(d=0.09, I C 90 \%=-0.19$ to 0.37$)$.

Differences between $5 \times 6$ vs $3 \times 10$ was moderate for BB ( $d=0.67$, IC $90 \%=0.30$ to 1.04 ), small to 1 RM $M_{\text {elbow extension }}(d=-0.41, I C 90 \%=-0.93$ to $0.11), V L(d=-0.47, I C 90 \%=-0.99$ to 0.05$)$ and trivial to $1 R^{R M}{ }_{\text {squat }}(d=-0.11$, IC $90 \%=-0.53$ to 0.31$), 1 R_{\text {biceps curl }}(d=0.17, I C 90 \%=-0.18$ to 0.52$)$ and TB ( $d=-0.17$, IC $90 \%=-0.61$ to 0.27$)$.

In comparison $10 \times 3$ vs $5 \times 6$ variables $1 R^{2} M_{\text {elbow extension }}(d=-0.55,1 C 90 \%=$ 1.07 to -0.03$), 1 \mathrm{RM}_{\text {squat }}(\mathrm{d}=0.01, \mathrm{IC} 90 \%=-0.43$ to 0.45$), 1 \mathrm{RM}$ biceps curl $(\mathrm{d}=0.34$, IC90\% $=-0.18$ to 0.86$), V L(d=-0.40, I C 90 \%=-0.08$ to -0.72$)$ and TB ( $d=0.11$, IC90\% $=-0.30$ to 0.52 ) presented trivial or small ES. Moderate ES in BB was found in $10 \times 3$ vs $5 \times 6$ ( $d=0.62$, IC90\%=-0.02 to 1.26$)$.

As shown at Figure 2 no significant effect of groups was observed for accumulated total load lifted $\left(F_{1,13}=2.536, p=0.582, \eta_{p}^{2}=0.089\right)$

Significant correlations ( $p<0.0001)$ were found between maximum strength and muscle thickness for biceps and triceps brachii singly (Table 4). Additionally, significant correlations ( $p<0.0001$ ) were found on general analyses between maximum strength and muscle thickness for all muscles analyzed as showed at Figure 3.

Table 2. Muscle strength measures after 8 weeks of training.

\begin{tabular}{|c|c|c|c|c|c|c|}
\hline \multirow{3}{*}{ Parameters } & \multirow{3}{*}{ Before } & \multirow{3}{*}{ After } & \multirow{3}{*}{$\Delta \%$} & \multirow{2}{*}{ Cohen } & \multicolumn{2}{|c|}{ ANOVA $3 \times 2$} \\
\hline & & & & & time & time* group \\
\hline & & & & ES & $p$ value & $p$ value \\
\hline \multicolumn{7}{|c|}{$1 \mathrm{RM}_{\text {biceps curl }}(\mathrm{kg})$} \\
\hline $3 \times 10$ & $29 \pm 10$ & $38 \pm 11^{\mathrm{a}}$ & 30.3 & 0.86 & 0.001 & \multirow{3}{*}{0.414} \\
\hline $10 \times 3$ & $29 \pm 15$ & $38 \pm 17^{a}$ & 33.2 & 0.60 & 0.001 & \\
\hline $5 \times 6$ & $30 \pm 10$ & $38 \pm 10^{\mathrm{a}}$ & 27.8 & 0.79 & 0.001 & \\
\hline \multicolumn{7}{|l|}{$1 \mathrm{RM}_{\text {squat }}(\mathrm{kg})$} \\
\hline $3 \times 10$ & $156 \pm 41$ & $206 \pm 43^{a}$ & 32.4 & 1.20 & 0.001 & \multirow{3}{*}{0.973} \\
\hline $10 \times 3$ & $152 \pm 73$ & $206 \pm 85^{a}$ & 35.3 & 0.68 & 0.001 & \\
\hline $5 \times 6$ & $155 \pm 54$ & $209 \pm 64^{a}$ & 34.3 & 0.90 & 0.001 & \\
\hline \multicolumn{7}{|c|}{$1 \mathrm{RM}_{\text {elbow extension }}(\mathrm{kg})$} \\
\hline $3 \times 10$ & $56 \pm 18$ & $69 \pm 19^{a}$ & 22.8 & 0.69 & 0.001 & \multirow{3}{*}{0.375} \\
\hline $10 \times 3$ & $54 \pm 20$ & $66 \pm 23^{a}$ & 20.8 & 0.52 & 0.001 & \\
\hline $5 \times 6$ & $55 \pm 18$ & $69 \pm 16^{a}$ & 26.8 & 0.86 & 0.001 & \\
\hline
\end{tabular}

Values expressed in mean \pm SD of $3 \times 10$ group, $10 \times 3$ group and $6 \times 5$ group. One maximal repetition test (1RM). Effect size (ES). ${ }^{a}$ significant $(p<0.05)$ differences to before

Table 3. Muscle thickness measures after 8 weeks of training

\begin{tabular}{|c|c|c|c|c|c|c|}
\hline \multirow{3}{*}{ Parameters } & \multirow{3}{*}{ After } & \multirow{3}{*}{ Before } & \multirow{3}{*}{$\Delta \%$} & \multirow{2}{*}{ Cohen } & \multicolumn{2}{|c|}{ ANOVA $3 \times 2$} \\
\hline & & & & & time & time* group \\
\hline & & & & ES & $p$ value & $p$ value \\
\hline \multicolumn{7}{|l|}{$\mathrm{BB}(\mathrm{mm})$} \\
\hline $3 \times 10$ & $34.6 \pm 6.9$ & $39.3 \pm 6.8^{a}$ & 13.7 & 0.69 & 0.001 & \multirow{3}{*}{0.226} \\
\hline $10 \times 3$ & $34.9 \pm 6.5$ & $39.4 \pm 6.7^{a}$ & 13.0 & 0.69 & 0.001 & \\
\hline $5 \times 6$ & $35.0 \pm 7.8$ & $38.4 \pm 7.9^{a}$ & 9.8 & 0.44 & 0.001 & \\
\hline \multicolumn{7}{|l|}{$\mathrm{TB}(\mathrm{mm})$} \\
\hline $3 \times 10$ & $35.4 \pm 3.9$ & $39.8 \pm 4.4^{\mathrm{a}}$ & 12.2 & 1.03 & 0.001 & \multirow{3}{*}{0.884} \\
\hline $10 \times 3$ & $35.0 \pm 5.5$ & $40.1 \pm 4.7^{a}$ & 14.4 & 0.98 & 0.001 & \\
\hline $5 \times 6$ & $34.3 \pm 3.4$ & $39.0 \pm 2.7^{a}$ & 13.8 & 1.54 & 0.001 & \\
\hline \multicolumn{7}{|l|}{$\mathrm{VL}(\mathrm{mm})$} \\
\hline $3 \times 10$ & $40.7 \pm 5.5$ & $45.2 \pm 6.3^{\mathrm{a}}$ & 11.2 & 0.77 & 0.001 & \multirow{3}{*}{0.775} \\
\hline $10 \times 3$ & $40.9 \pm 4.7$ & $45.7 \pm 4.9^{a}$ & 11.8 & 1.01 & 0.001 & \\
\hline $5 \times 6$ & $40.5 \pm 5.0$ & $46.3 \pm 5.6^{a}$ & 14.5 & 1.11 & 0.001 & \\
\hline
\end{tabular}

Values expressed in mean \pm SD of $3 \times 10$ group, $10 \times 3$ group and $6 \times 5$ group. Muscle thickness of the biceps brachii and brachialis (BB), triceps brachii (TB) and vastus lateralis (VL). Effect size (ES). ${ }^{2}$ significant $(\mathrm{p}<0.05)$ differences to before. 


\section{DISCUSSION}

The present study aimed to investigate the chronic effect of 8 weeks of strength training with different numbers of sets and total equalized cumulative load on maximal strength and muscle thickness of adult subjects. From the findings, we highlight that regardless of the number of sets and maximum repetitions, the improvement of maximum force in the squat, flexion and elbow extension as well as the muscular thickness

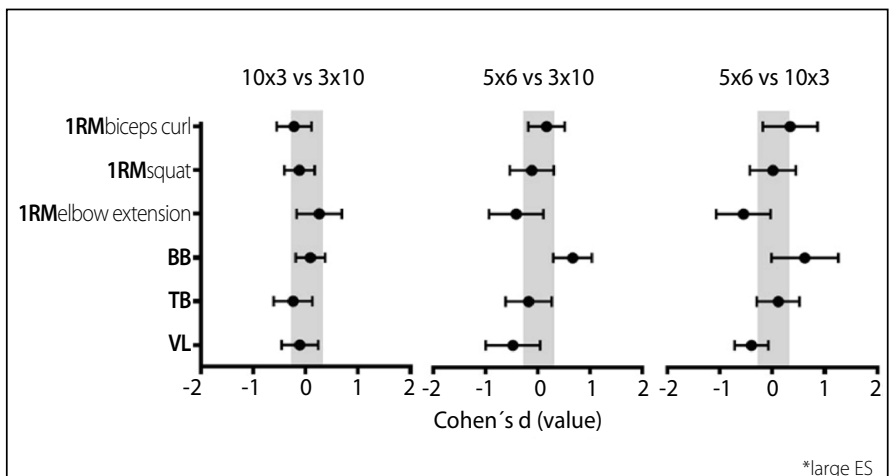

Figure 1. Cohen's effect size (ES) principle $\pm 90 \%$ confidence intervals was used to compare the absolute differences of $3 \times 10$ group, $10 \times 3$ group and $6 \times 5$ group. One maximal repetition test (1RM) and muscle thickness of the biceps brachii and brachialis (BB), triceps brachii (TB) and vastus lateralis (VL).

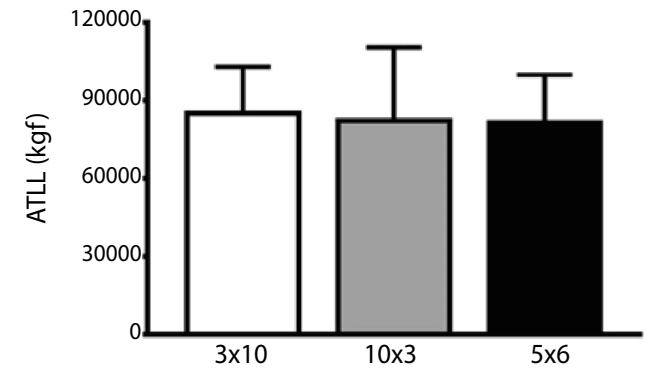

Figure 2. Weekly accumulated total load lifted (ATLL) of subjects during the 8-weeks of intervention training of $3 \times 10$ group, 10×3 group and $6 \times 5$ group.

Table 4. Correlation between maximum strength and muscle thickness of muscle biceps brachii, triceps brachii and vastus lateralis according to strength protocol.

\begin{tabular}{|c|c|c|c|}
\hline \multirow{2}{*}{ Strength protocol } & \multicolumn{3}{|c|}{ Muscle } \\
\hline & Biceps brachii & Triceps brachii & Vastus lateralis \\
\hline $3 \times 10$ & $\begin{array}{l}r: 0.8196 \\
p<0.0001\end{array}$ & $\begin{array}{l}r: 0.5377 \\
p=0.0007\end{array}$ & $\begin{array}{l}r: 0.2394 \\
p=0.1597\end{array}$ \\
\hline $10 \times 3$ & $\begin{array}{l}r: 0.8018 \\
p<0.0001\end{array}$ & $\begin{array}{l}r: 0.6005 \\
p=0.0007\end{array}$ & $\begin{array}{l}r: 0.5124 \\
p=0.0053\end{array}$ \\
\hline $5 \times 6$ & $\begin{array}{l}r: 0.8481 \\
p<0.0001\end{array}$ & $\begin{array}{l}r: 0.5241 \\
p=0.0021\end{array}$ & $\begin{array}{l}r: 0.3488 \\
p=0.0504\end{array}$ \\
\hline
\end{tabular}

of the biceps, triceps and vastus lateralis occurs similarly when the load total accumulated in the week is equalized.

In fact, when advanced techniques or unconventional training methods are not used, much of the literature suggests that different training schemes (loads, repetition zones, etc.), when equalized for total accumulated load, result in similar gains, in hypertrophy and strength, in both trained and untrained individuals $17,23,24$

Another factor to consider is that in our study all 3 protocols were performed until concentric failure, regardless of the absolute training intensity. Recent evidence demonstrates that when performed to muscle failure, low-load training can be as effective as moderate or high-weight training ${ }^{25,26}$. This may be to the fact that training to muscle failure generates greater metabolic stress, in addition to increasing muscle fiber recruitment ${ }^{26}$. This suggests that training using variable loads can be used as a strategy to generate greater dynamism in training routines without impairing muscle hypertrophy.

Although some studies have shown discrepancy in maximal force between exercise protocols with high and low repetitions ${ }^{17,27}$ our results show that maximal strength gain did not differ between groups, these findings are in agreement with previous studies ${ }^{11,24,28,29}$. Lopes et al. ${ }^{24}$ evaluated the effects of different load schemes on strength and body composition in trained men during 6 weeks of resistance training. The volunteers were divided into two groups: 6 sets of 10 repetitions (moderate load) versus 3 sets of 20 repetitions (light load). Both training routines were performed until concentric failure four times during a week. The results demonstrated that both groups had similar 1RM gains in bench press (6.4\% for the moderate load group and $4.9 \%$ for the light load group) and squat (10.5\% and $8 \%$ for the moderate load and light load group, respectively).

Fink et al. ${ }^{28}$ also found similar gains in both strength and hypertrophy after 8 weeks of training in 21 untrained men who were divided into groups that trained with high loads ( 3 sets of 8-12 RM) and another with lower loads (3 sets of 30 to 40 repetitions). These data, however, do not corroborate other studies showing that higher loads generate greater strength gains ${ }^{30}$. Another interesting finding from this study was that although all three protocols resulted in similar fiber transformation (IIB for IIA), programs with low to intermediate volume repetitions induced a greater hypertrophic effect compared to the high repetition regimen. The discrepancies between this study and our study can be attributed to the exercises used, the training level of the volunteers, and the training protocols that were different from the ones used in this study ${ }^{24}$.

An interesting finding was the significant correlation found between maximum strength and muscle thickness only in biceps and triceps brachii but not on vastus lateralis (table 4). To the best of our knowledge Kubo et al. ${ }^{17}$ demonstrated significant correlations in relative changes in 1RM and muscle volume of pectoralis major in a 12RM group, but not in a 4RM or 8RM group. Differently from Kubo's study, our study
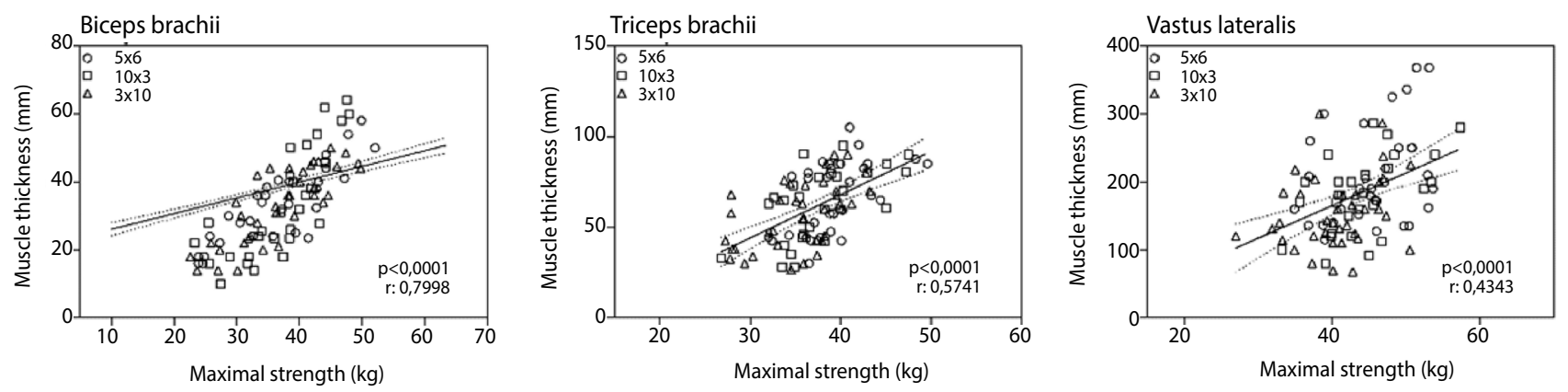

Figure 3. General correlation between maximum strength and muscle thickness of muscle biceps brachii, triceps brachii and vastus lateralis. 
found differences in muscle type independently of changes in muscle strength induced by different protocols. Scientific hypothesis may be used to address volume area changes of the vastus lateralis muscle but does not singly explain the maximal strength gain observed. Further studies and hypothesis are needed to clarify and confirm our findings using cross-sectional images of several muscle groups with 3T magnetic resonance imaging and prolongation of training period.

Briefly, the results demonstrate that there was no difference in the relative increase in muscle volume and maximal strength using different protocol repetitions $(3 \times 10,10 \times 3$ and $5 \times 6)$ during volume-equated training. It should be emphasized that the variation of methods can be an interesting strategy to promote strength gains, keep subjects motivated, avoid monotony and promote adherence to training programs.
In conclusion, all protocols used promoted similar increases in strength and muscle thickness in physically active individuals. This suggests that regardless of the number of sets and maximal repetitions, neuromuscular and morphological adaptations will occur similarly when the volume of repetitions is equalized during the training session.

\section{ACKNOWLEDGMENTS}

This work was supported by grants from Fundação de Amparo a Pesquisa do Espírito Santo (grant number 84417625/2018). The funders had no role in study design, data collection and analysis, decision to publish, or preparation of the manuscript.

All authors declare no potential conflict of interest related to this article

AUTHORS' CONTRIBUTIONS: Each author made significant individual contributions to this manuscript. ALE, TVB, RLR: preparation of the entire research project, writing, selection of participants and data collection, data review and analysis, editing, statistical analysis, discussion of results and execution of the revision; WAB, ACA: revision and correction analysis; JBA, BMB, MRRP: editing, revision and tabulation of data; RLR: critical review, text analysis and writing; JSB, JMDG, DSB: intellectual concept and revision; ALE, JMDG, DSB: guidance for the preparation of the project and study design, selection of participants and data collection, discussion of results, intellectual concept, contribution to the conception and editing and revision. All authors reviewed and approved the final version of the manuscript.

\section{REFERENCES}

1. Bottaro M, Veloso J, Wagner D, Gentil P. Resistance training for strength and muscle thickness: effect of number of sets and muscle group trained. Sci Sport. 2011;26(2):259-64.

2. Haff G, Triplett NT. Principles of test selection and administration. In: Essentials of Strength Training and Conditioning. Champaign, IL: Human Kinetics; 2015.

3. Helms E, Fitschen PJ, Aragon A, Cronin J, Schoenfeld BJ. Recommendations for natural bodybuilding contest preparation: resistance and cardiovascular training. J Sports Med Phys Fitness. 2015;55(3):164-78.

4. Ostrowski KJ, Wilson GJ, Weatherby R, Murphy PW, Lyttle AD. The effect of weight training volume on hormonal output and muscular size and function. J Strength Cond Res. 1997;11:148-54.

5. Radaelli R, Fleck SJ, Leite T, Leite RD, Pinto RS, Fernandes $L$, et al. Dose-response of 1, 3 , and 5 sets of resistance exercise on strength, local muscular endurance, and hypertrophy. J Strength Cond Res. 2015;29(5):1349-58.

6. Ronnestad BR, Egeland W, Kvamme NH, Refsnes PE, Kadi F, Raastad T. Dissimilar effects of one- and three-set strength training on strength and muscle mass gains in upper and lower body in untrained subjects. J Strength Cond Res. 2007;21(1):157-63.

7. Teixeira CVLS, Pereira EFM, Evangelista AL Lopes CR, Guedes Júnior DP, Schoenfeld BJ, et al. Is the weekly sets volume training performed by trained subjects in accordance with training recommendations guidelines for muscle hypertrophy? Motriz: Rev Educ Fis. 2018;24(2):e101815.

8. Snyder G, Wayne R. Posedown: muscletalk with the champs. New York: Sterling Publisher; 1987.

9. Hackett DA, Johnson NA, Chow CM. Training practices and ergogenic aids used by male bodybuilders. J Strength Cond Res. 2013;27(6):1609-17.

10. Schoenfeld BJ, Ogborn D, Krieger JW. Dose-response relationship between weekly resistance training volume and increases in muscle mass: A systematic review and meta-analysis. J Sports Sci. 2017;35(11):1073-82.

11. Schoenfeld BJ, Ratamess NA, Peterson MD, Contreras B, Sonmez GT, Alvar BA. Effects of different volume-equated resistance training loading strategies on muscular adaptations in well-trained men. J Strength Cond Res. 2014;28(10):2909-18.

12. Barbalho M, Coswig VS, Steele J, Fisher JP, Giessing J, Gentil P. Evidence of a ceiling effect for training volume in muscle hypertrophy and strength in trained men - less is more? Int J Sports Physiol Perform. 2020;15(2):268-77.

13. Dankel SJ, Mouser JG, Mattocks KT, Counts BR, Jessee MB, Buckner SL, et al. The widespread misuse of effect sizes. J Sci Med Sport. 2017;20(5):446-50.

14. Teixeira CVLS, Motoyama Y, de Azevedo PHSM, Evangelista AL, Steele J, Bocalini DS. Effect of resistance training set volume on upper body muscle hypertrophy: are more sets really better than less? Clin Physiol Funct Imaging. 2018;38(5):727-32.

15. Hopkins WG, Marshall SW, Batterham AM. Progressive statistics for studies in sports medicine and exercise science. Med Sci Sports Exerc. 2009;41(1):3-13.
16. Burd NA, West DW, Staples AW, Atherton PJ, Baker JM, Moore DR, et al. Low-load high volume resistance exercise stimulates muscle protein synthesis more than high-load low volume resistance exercise in young men. PLoS One. 2010;5(8):e12033.

17. Kubo K Ikebukuro T, Yata H. Effects of 4, 8, and 12 repetition maximum resistance training protocols on muscle volume and strength. J Strength Cond Res. 2020.

18. Matsudo S, Araújo T, Matsudo V, Andrade D, Andrade E, Oliveira LC, et al. International physical activity questionnaire (IPAQ): study of validity and reability in Brazil. Rev Bras Ativ Fís Saúde. 2001;6:5-18.

19. American College of Sports Medicine Position Stand. Progression models in resistance training for healthy adults. Med Sci Sports Exerc. 2009;41(3):687-708.

20. Evangelista AL, de Souza EO, Moreira DCB, Alonso AC, Teixeira CVLS, Wadhi T, et al. Interset stretching vs. traditional strength training: effects on muscle strength and size in untrained individuals. Strength Cond Res. 2019;33 Suppl 1:S159-66.

21. Evangelista AL, Teixeira CVS, Barros BM, de Azevedo JB, Paunksnis MRR, Wadhi T, et al. Does wholebody electrical muscle stimulation combined with strength training promote morphofunctional alterations? Clinics. 2019;7(74):e1334.

22. Weissgerber TL, Milic NM, Winham SJ, Garovic VD. Beyond bar and line graphs: time for a new data presentation paradigm. PLoS Biol. 2015;13(4):e1002128.

23. Barroso R, Rochel H, Ugrinowitsc C, Araújo R, Nosaka K, Tricoli V. Effect of eccentric contraction velocity on muscle damage in repeated bouts of elbow flexor exercise. Appl Physiol Nutr Metab. 2010;35(4):534-40

24. Lopes CR, Aoki MS, Crisp AH, de Mattos RS, Lins MA, da Mota GR, et al. The effect of different resistance training load schemes on strength and body composition in trained men. J Hum Kinet. 2017;58:177-86.

25. Gołaś A, Maszczyk A, Pietraszewski P, Stastny P, Tufano, JJ, Zając A. Effects of Pre-exhaustion on the Patterns of Muscular Activity in the Flat Bench Press. J Strength Cond Res. 2017;31(7):1919-24.

26. Schoenfeld BJ, Peterson MD, Ogborn D, Contreras B, Sonmez GT. Effects of low-versus high-load resistance training on muscle strength and hypertrophy in well-trained men. J Strength Cond Res. 2015;29(10):2954-63.

27. Campos GER, Luecke TJ, Wendeln HK, Toma K, Hagerman FC, Murray TF, et al. Muscular adaptations in response to three different resistance-training regimens: Specificity of repetition maximum training zones. Eur J Appl Physiol. 2002;88(1-2):50-60.

28. Fink J, Kikuchi N, Yoshida S, Terada K, Nakazato K. Impact of high versus low fixed loads and non-linear training loads on muscle hypertrophy, strength and force development. Springerplus. 2016;5(1):698.

29. Mangine GT, Hoffman JR, Gonzalez AM, Townsend JR, Wells AJ, Jajtner AR, et al. The effect of training volume and intensity on improvements in muscular strength and size in resistance-trained men. Physiol Rep. 2015;3(8):e12472.

30. Schoenfeld BJ, Grgic J, Ogborn D, Krieger JW. Strength and hypertrophy adaptations between low- vs. high-load resistance training: a systematic review and meta-analysis. J Strength Cond Res. 2017;31(12):3508-23

\section{ERRATA}

In the article entitled"THE DOSE-RESPONSE PHENOMENON ASSOCIATEDWITH STRENGTHTRAINING IS INDEPENDENT OF THEVOLUME OF SETS AND REPETITIONS PER SESSION"authored by Alexandre L. Evangelista, Tiago V. Braz, Roberta L. Rica, Welmo A. Barbosa, Angelica C. Alonso, Jonatas B. Azevedo, Bruna M. Barros, Julien S. Baker, Danilo S. Bocalini, Julia M. D. Greve, published in Rev Bras Med Esporte [online] 2021, vol.27, n.1. DOI: https://doi.org/10.1590/15178692202127012020_0058, pages 108-112, by request of the authors.

- where it reads: Squat and/or back squat

- read: Leg press

on page 109 lest paragraph of Study design:

- Where it reads: Each training session lasted approximately between 20 and 60 minutes.

- Read: Each training session lasted approximately between 20 and 60 minutes. The weekly accumulated total load lifted (ATLL was calculated by multiplying the number of sets by the number of repetitions by the lifted load (sets $x$ repetitions $x$ load). 
In the article entitled "THE DOSE-RESPONSE PHENOMENON ASSOCIATED WITH STRENGTH TRAINING IS INDEPENDENT OF THE VOLUME OF SETS AND REPETITIONS PER SESSION" authored by Alexandre L. Evangelista, Tiago V. Braz, Roberta L. RicaWelmo A. Barbosar Angelica C. Alonso, Jonatas B. Azevedo, Bruna M. Barros, Julien S. Baker, Danilo S. Bocalini, Julia M. D. Greve, published in Rev Bras Med Esporte [online] 2021, vol.27, n.1. DOI: https://doi.org/10.1590/1517-8692202127012020_0058, pages 108-112, by request of the authors.

On Page 109, first paragraph

- Where it reads: During the study period, 13 individuals dropped out due to personal reasons,

- Read: During the study period, 19 individuals dropped out due to personal reasons,

\section{On Page 110, Statistical analyses}

- Where it reads: All analyses were conducted in SPSS-22.0 software (IBM Corp., Armonk, NY, USA). The adopted significance was P $\leq 0.05$.

- Read: The relationship between variables was determined through Pearson correlation. All analyses were conducted in SPSS-22.0 software (IBM Corp., Armonk, NY, USA). The adopted significance was $P \leq 0.05$.

\section{On page 110, paragraph 7 - RESULTS}

- Where it reads: Significant correlations ( $p<0.0001)$ were found between maximum strength and muscle thickness for biceps and triceps brachii singly (Table 4). Additionally, significant correlations ( $p<0.0001$ ) were found on general analyses between maximum strength and muscle thickness for all muscles analyzed as showed at Figure 3.

- Read: Significant correlations ( $p<0.05$ ) were found between maximum strength and muscle thickness for biceps brachii, triceps brachii and vastus lateralis (Table 4). No significant correlation were found for $3 \times 10$ protocol in vastus lateralis muscle $(r=0.3178, p=0.5852)$. Additionally, significant correlations ( $p<0.0001$ ) were found on general analyses between maximum strength and muscle thickness for all muscles analyzed as showed at Figure 3 .

On page 111 - Table 4

- Where it reads:

- Read:

Table 4. Correlation between maximum strength and muscle thickness of muscle biceps brachii, triceps brachii and vastus lateralis according to strength protocol.

\begin{tabular}{c|c|c|c}
\hline \multirow{2}{*}{ Strength protocol } & \multicolumn{3}{|c}{ Muscle } \\
\cline { 2 - 4 } & Biceps brachii & Triceps brachii & Vastus lateralis \\
\hline \multirow{2}{*}{$3 \times 10$} & $\mathrm{r}: 0.8196$ & $\mathrm{r}: 0.5377$ & $\mathrm{r}: 0.2394$ \\
& $\mathrm{p}<0.0001$ & $\mathrm{p}=0.0007$ & $\mathrm{p}=0.1597$ \\
\hline \multirow{2}{*}{$10 \times 3$} & $\mathrm{r}: 0.8018$ & $\mathrm{r}: 0.6005$ & $\mathrm{r}: 0.5124$ \\
& $\mathrm{p}<0.0001$ & $\mathrm{p}=0.0007$ & $\mathrm{p}=0.0053$ \\
\hline \multirow{2}{*}{$5 \times 6$} & $\mathrm{r}: 0.8481$ & $\mathrm{r}: 0.5241$ & $\mathrm{r}: 0.3488$ \\
& $\mathrm{p}<0.0001$ & $\mathrm{p}=0.0021$ & $\mathrm{p}=0.0504$ \\
\hline
\end{tabular}

Table 4. Correlation between maximum strength and muscle thickness of muscle biceps brachii, triceps brachii and vastus lateralis according to strength protocol.

\begin{tabular}{c|c|c|c}
\hline \multirow{2}{*}{ Strength protocol } & \multicolumn{3}{|c}{ Muscle } \\
\cline { 2 - 4 } & Biceps brachii & Triceps brachii & Vastus lateralis \\
\hline \multirow{2}{*}{$3 \times 10$} & $\mathrm{r}: 0.8196$ & $\mathrm{r}: 0.6384$ & $\mathrm{r}: 0.3178$ \\
& $\mathrm{p}<0.0001$ & $\mathrm{p}<0.0001$ & $\mathrm{p}=0.5852$ \\
\hline \multirow{2}{*}{$10 \times 3$} & $\mathrm{r}: 0.8018$ & $\mathrm{r}: 0.5831$ & $\mathrm{r}: 0.5979$ \\
& $\mathrm{p}<0.0001$ & $\mathrm{p}=0.0011$ & $\mathrm{p}=0.0008$ \\
\hline \multirow{2}{*}{$5 \times 6$} & $\mathrm{r}: 0.8481$ & $\mathrm{r}: 0.4914$ & $\mathrm{r}: 0.4278$ \\
& $\mathrm{p}<0.0001$ & $\mathrm{p}=0.0043$ & $\mathrm{p}=0.0146$ \\
\hline
\end{tabular}

On page 111- Figure 3

- Where it reads: Figure 3. General correlation between maximum strength and muscle thickness of muscle biceps brachii, triceps brachii and vastus lateralis.
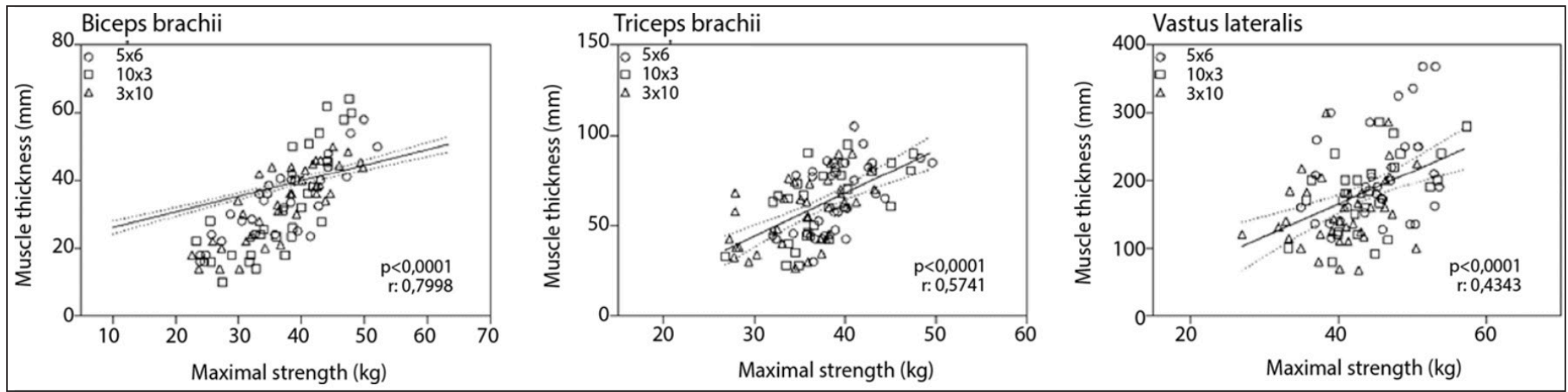


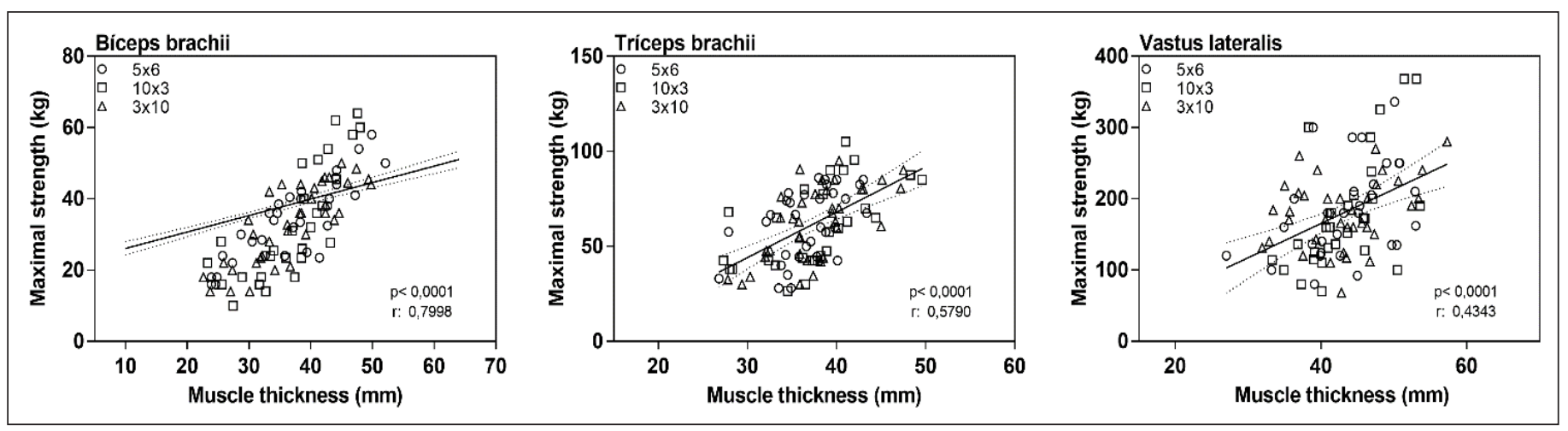

On page 111, paragraph 6 - DISCUSSION

- Where it reads: An interesting finding was the significant correlation found between maximum strength and muscle thickness only in biceps and triceps brachii but not on vastus lateralis (Table 4). To the best of our knowledge Kubo et al..$^{17}$ demonstrated significant correlations in relative changes in 1RM and muscle volume of pectoralis major in a 12RM group, but not in a 4RM or 8RM group. Differently from Kubo's study, our study found differences in muscle type independently of changes in muscle strength induced by different protocols. Scientific hypothesis may be used to address volume area changes of the vastus lateralis muscle but does not singly explain the maximal strength gain observed. Further studies and hypothesis are needed to clarify and confirm our findings using cross-sectional images of several muscle groups with 3T magnetic resonance imaging and prolongation of training period.

- Read: An interesting finding was the significant correlation found between maximum strength and muscle thickness for biceps brachii, triceps brachii and vastus lateralis (Table 4). To the best of our knowledge Kubo et al. ${ }^{17}$ demonstrated significant correlations in relative changes in 1RM and muscle volume of pectoralis major in a 12RM group, but not in a 4RM or 8RM group. Differently from Kubo's study, our study found differences in muscle type independently of changes in muscle strength induced by different protocols. Further studies and hypothesis are needed to clarify and confirm our findings using cross-sectional images of several muscle groups with 3D magnetic resonance imaging and prolongation of training period. 